\title{
Farmers' Perception of and Coping Strategies to Climate Change: Evidence From Six Agro-Ecological Zones of Uganda
}

\author{
Joshua S. Okonya ${ }^{1}$, Katja Syndikus ${ }^{2} \&$ Jürgen Kroschel $^{3}$ \\ ${ }^{1}$ International Potato Center (CIP), Kampala, Uganda \\ ${ }^{2}$ Institute of Marketecology, Weststrasse, Weinfelden, Switzerland \\ ${ }^{3}$ International Potato Center (CIP), Lima, Peru \\ Correspondence: Jürgen Kroschel, International Potato Center (CIP), Lima, Peru. E-mail: j.kroschel@cgiar.org
}

Received: April 18, 2013 Accepted: June 5, 2013 Online Published: July 15, 2013

doi:10.5539/jas.v5n8p252 URL: http://dx.doi.org/10.5539/jas.v5n8p252

\begin{abstract}
In Uganda, weather-related events such as prolonged dry seasons, floods, storms, mudslides, extreme rainfall, and delayed/early rains have become more frequent and/or intense. This has left most of the rural poor farmers' food insecure and their livelihoods threatened. A total of 192 sweetpotato farmer households distributed in six agro-ecological zones were interviewed to assess how farmers perceive the effects of changes in climatic variables, and how they have adjusted their farming practices to cope with the changes in climate. Gender of the household head and size of land owned significantly affected adaptation. Ninety nine percent of all households interviewed had observed a change in the climate in the last 10 years. Drought and floods had the highest impact on crop production across agro-ecological zones. Coping strategies towards extreme events included storing food, income diversification and digging drainage channels. Other strategies were planting trees; high-yielding, early-maturing, drought-tolerant, disease and/or pest-resistant varieties; planting at onset of rains; increased pesticide/fungicide application among others. The smallholder farmer households studied have a high awareness of changes in rainfall and temperature and have taken measures to cope with effects of a changing climate.
\end{abstract}

Keywords: climate variability, agriculture, farm-level adaptation, smallholder farmers, Uganda

\section{Introduction}

Global climate change is one of the most critical challenges facing the international community today. Climate change is threatening to undo decades of development efforts due to its negative impacts on agriculture, health, environment, roads, and buildings especially in developing countries (GoU, 2007; IPCC, 2007; Mendelsohn et al., 2006; Stern, 2007). From a food security perspective, sub-Saharan Africa (SSA) is arguably the most vulnerable region to many adverse effects of climate change due to a very high reliance on rainfed agriculture for basic food security and economic growth, and entrenched poverty (Dixon et al., 2001; IPCC, 2007; Cooper et al., 2008). Climate change is certain to amplify these vulnerabilities given projections of warming temperatures, potential for increased activity attributable to the El Niño Southern Oscillation and trends of increased aridity in southern Africa and other regions within Africa (Christensen et al., 2007; IPCC, 2007).

In countries like Senegal, China, Ghana, Nepal, Bangladesh, Nigeria, United States of America, farmers have been mentioned to perceive and even adapt to changes in the climate (Mertz et al., 2009; Byg \& Salick, 2009; Fosu-Mensah et al., 2010; Maharjan et al., 2011; Haque et al., 2011; Salau, 2012; Arbuckle et al., 2013). Socioeconomic and environmental factors have been demonstrated in various studies to influence farmers' perception and adaptation to changes in the climate (Deressa et al., 2011), those include education, household size, livestock ownership, agro-ecological zone, farm size and access to credit among others. However, Gukurume (2013) reported that peasant farmers in Bikita district, Zimbabwe, had no adaptive capacity due to extreme poverty levels and reliance on basic technologies.

Coping strategies that have been recommended for instance in Ethiopia to lessen the negative impacts of climate change include encouraging livestock ownership, planting early-maturing and drought-tolerant crop varieties, investment in irrigation, and strengthening research institutions (Deressa \& Hassan, 2009). In Ghana, Fosu-Mensah et al. (2010) identified crop diversification and changing planting dates for crop plants as the two 
most common adaptation strategies used by farmers. In Zimbabwe, crop and livelihood diversification were the main coping strategies used to reduce the risk of crop failure and livelihood vulnerability (Gukurume, 2013).

Despite Uganda being highly vulnerable to rainfall variability and climatic shocks like droughts and floods (MoWE, 2002; GoU, 2007; GoU, 2010; MoWE, 2010), micro-level studies at the farm-level on how rural smallholder farmers perceive these changes are limited. Most studies assessing the potential effects of climate change on African agriculture are regional or national and yet adaptation is place-based and needs the use of place-specific strategies (Fischer et al., 2002; Hassan \& Nhemachena, 2008; Kurukulasuriya \& Mendelsohn, 2008; Lobell et al., 2008; Seo et al., 2009; Deressa et al., 2011). There is also limited knowledge on whether farmers perceive climate change and how they are responding to the effects of a changing climate. It is also important to note that local perceptions cannot be estimated by models and the need to document how the lives of the local people are affected by the recent changes in climate.

This study therefore examined how rural smallholder farmers in different agro-ecological zones in Uganda perceive the effects of changes in climatic variables, and how they have adjusted their farming practices to cope with the changes in climate. Place-based perceptions and farm-level coping strategies of resource-constrained peasant farmers in Uganda are not documented. Specifically, we identified the major factors and quantified the extent to which these factors influence perceptions of climate change; further, we investigated actual farm-level coping strategies and documented how changes in climate affect crop production in six different agro-ecological zones of Uganda. We hypothesized that perceptions of and adaptation to climate change is highly influenced by the socioeconomic and environmental factors under which farmers live.

\section{Materials and Methods}

\subsection{Survey Design and Study Area}

A cross sectional household survey was carried out using a standard structured questionnaire applying both qualitative and quantitative methods of data collection and analysis. The questionnaire assessed demographic characteristics, perceptions of changes in rainfall, temperature and extreme weather events in the last 10 years, how changes in climate have affected crop production in the last 10 years and the changes made by farmers on their farms within the last 10 years because of changes in climate. The questionnaire was pre-tested on five households in Zirobwe, Luwero district and accordingly revised to produce the final questionnaire that was used in the study.

Interviews were conducted in six districts distributed among six agro-ecological zones of Uganda (Table 1). At least two sub-counties were covered in each district. District selection was based on a representation of the different agro-ecological zones of Uganda. Based on the above criteria a multi-stage, purposive sampling method was used to select the districts and the sub-counties. Selection of the villages and parishes to be surveyed was further guided by knowledge of local leaders and ease of accessibility. Respondents were distributed in 180 villages, 59 parishes, 17 sub-counties and six districts. Enumerators were first trained on the study tools and questionnaires prior to the data collection exercise. One respondent per household and per village or a distance of $5-10 \mathrm{~km}$ apart were considered for the study. People who were about 30 years of age or more and had lived in that village for the past 10 years or more were only considered in the study to ensure that respondents make meaningful comparisons between the past and the present. Interviews of the selected respondents were conducted in their homes. The number of respondents interviewed per district was 32 and included male, female, elderly and young farmers. A total of 192 farmer households were interviewed individually between August and October 2011. 
Table 1. Characteristics of the six agro-ecological zones (AEZ) under study

\begin{tabular}{|c|c|c|}
\hline AEZ (district) & Description of AEZ & Agricultural practices \\
\hline Eastern Savannah (Soroti) & $\begin{array}{l}\text { Rainfall from } 800-1500 \mathrm{~mm} \text {, } \\
1,200-1,340 \mathrm{~m} \text { asl., generally flat with } \\
\text { undulating hills, moderate to good } \\
\text { soils. }\end{array}$ & $\begin{array}{l}\text { Rainfed agriculture, consisting of } \\
\text { cereals, oil crops and pulses with } \\
\text { moderate livestock rearing. Paddy rice } \\
\text { grown in drained swamps. }\end{array}$ \\
\hline Lake Albert Crescent (Masindi) & $\begin{array}{l}\text { Rainfall from } 800-1,400 \mathrm{~mm} \text {, } \\
620-1,585 \mathrm{~m} \text { asl., generally flat with } \\
\text { undulating hills. Soils are good to } \\
\text { moderate. }\end{array}$ & $\begin{array}{l}\text { Rainfed mixed farming of maize Zea } \\
\text { mays L., pulses, root crops, coffee and } \\
\text { livestock rearing. }\end{array}$ \\
\hline $\begin{array}{l}\text { Lake Victoria Crescent } \\
\text { (Wakiso) }\end{array}$ & $\begin{array}{l}\text { Rainfall of } 1,200-1,450 \mathrm{~mm}, \\
1,000-1,800 \mathrm{~m} \text { asl., hilly and flat areas, } \\
\text { some with wetlands and forest. Soils } \\
\text { good to moderate. }\end{array}$ & $\begin{array}{l}\text { Mixed cropping of bananas, Robusta } \\
\text { coffee Coffea robusta Pierre ex } \\
\text { A.Froehner, vegetables, maize and } \\
\text { moderate dairy farming. Mostly } \\
\text { rainfed. }\end{array}$ \\
\hline $\begin{array}{l}\text { Northern Farming System } \\
\text { (Gulu) }\end{array}$ & $\begin{array}{l}\text { Average rainfall } 1200 \mathrm{~mm}, 975-1,520 \\
\mathrm{~m} \text { asl., generally flat with isolated } \\
\text { hills, fairly heavy fertile soils. }\end{array}$ & $\begin{array}{l}\text { Rainfed crop cultivation, consisting of } \\
\text { sorghum Sorghum sp., pearl millet } \\
\text { Eleusine coracana Gaertn., cassava, } \\
\text { sesame Sesamum indicum L. and } \\
\text { pulses. Some rearing of cattle and small } \\
\text { ruminants. }\end{array}$ \\
\hline $\begin{array}{l}\text { South Western Highlands } \\
\text { (Kabale) }\end{array}$ & $\begin{array}{l}\text { Rainfall }>1400 \mathrm{~mm} \text {, altitude } \\
1,300-3,960 \mathrm{~m} \text { mountainous areas of } \\
\text { Mt. Muhavura with mostly volcanic } \\
\text { rich soils. }\end{array}$ & $\begin{array}{l}\text { Rainfed mixed farming involving } \\
\text { mostly stall fed cattle, small ruminants, } \\
\text { and vegetables, tubercrops such as } \\
\text { potato. }\end{array}$ \\
\hline Western Range Lands (Kasese) & $\begin{array}{l}\text { Rainfall } 915-1020 \mathrm{~mm} \text {, altitude } \\
600-1,524 \mathrm{~m} \text {, rolling hills with some } \\
\text { flat areas, soils are moderate to poor }\end{array}$ & $\begin{array}{l}\text { Cattle rearing is predominant mixed in } \\
\text { places with banana } M u s a \text { sp. } \\
\text { production }\end{array}$ \\
\hline
\end{tabular}

Source: http://www.fao.org/agriculture/seed/cropcalendar/aezones.do?isocode=UGA.

Table 2. Description of model variables of the selection equation for the Heckman probit selection model

\begin{tabular}{|c|c|c|}
\hline 1. Dependent variable & $\begin{array}{l}\text { Farmers who } \\
\text { perceived climate } \\
\text { change }(\%)\end{array}$ & $\begin{array}{ll}\text { Farmers who } \\
\text { did } \\
\text { perceive } \\
\text { climate } \\
\text { change }(\%) \\
\end{array}$ \\
\hline $\begin{array}{l}\text { Perception of climate change (dummy: takes the value of } 1 \text { if farmer has perceived a } \\
\text { change in the last } 10 \text { years and } 0 \text { otherwise) } \\
\text { 2. Independent variables }\end{array}$ & 99.0 & 1.0 \\
\hline Description & Mean & S.D. \\
\hline $\begin{array}{l}\text { Level of education of household head (dummy: takes the value of } 1 \text { if above A level } \\
\text { and } 0 \text { otherwise) }\end{array}$ & 0.06 & 0.2 \\
\hline Age of the household head (years; continuous) & 43.3 & 12.7 \\
\hline Social capital (dummy: 1 if member of a farmers group and otherwise 0 ) & 0.4 & 0.5 \\
\hline Off-farm income source (dummy: 1 if present otherwise 0 ) & 0.4 & 0.5 \\
\hline Weather forecast and climate information (dummy: 1 if received otherwise 0 ) & 0.5 & 0.5 \\
\hline $\begin{array}{l}\text { Traditional knowledge of local early warning signs ( dummy: } 1 \text { if uses local signs to } \\
\text { predict seasons and } 0 \text { if otherwise) }\end{array}$ & 0.6 & 0.5 \\
\hline Extension information on sweetpotato crop (dummy: 1 if received otherwise 0 ) & 0.1 & 0.3 \\
\hline Farming experience (continuous) & 22.3 & 12.6 \\
\hline Elevation (m above sea level; continuous) & 1261.6 & 380.8 \\
\hline AEZ is Northern farming system ( dummy: 1 if Gulu otherwise 0 ) & 0.2 & 0.4 \\
\hline AEZ is South Western Highlands (dummy: 1 if Kabale otherwise 0) & 0.2 & 0.4 \\
\hline AEZ is Western Range Lands (dummy: 1 if Kasese 0 if otherwise) & 0.2 & 0.4 \\
\hline AEZ is Lake albert Crescent (dummy: 1 if Masindi and 0 if otherwise) & 0.2 & 0.4 \\
\hline AEZ is Eastern Savannah (dummy: 1 if Soroti, 0 if otherwise) & 0.2 & 0.4 \\
\hline AEZ is Lake Victoria Crescent (dummy: 1 if Wakiso and 0 if otherwise) & 0.2 & 0.4 \\
\hline
\end{tabular}




\subsection{Statistical Analysis}

Data was entered using MS Excel and exported to STATA for basic descriptive statistical analyses. Frequencies and means were the major statistical tools that were used to enable the description of farmers' perceptions about changes in climatic variables and plant health as well the coping strategies being practiced to mitigate the effects of a changing climate.

\subsection{Empirical Model}

As previous authors have found, perception and coping strategies to climate change are influenced by a number of socioeconomic and environmental factors (Nhemachena \& Hassan, 2007; Deressa et al., 2009; Nhemachena, 2009; Deressa et al., 2010). We therefore hypothesized that factors which affect perception and the development of strategies to cope with changes in climate will include agroecology, gender, age, household size, land holding, farm labor, ability to pay/hire labor, ownership of livestock, non-farm income source, access to credit, social capital, farming experience, practice of irrigation, use of farm inputs such as fertilizers and pesticides, receiving weather forecast, intercropping on the farm and the use of local signs to predict seasons. A two-step regression model (Heckman selection model) was used for this study because farmers first perceive and then develop strategies to cope with climate change.

\subsection{Dependent and Independent Variables}

Dependent variables are:

i) whether a farmer has or has not perceived climate change (Table 3);

ii) whether a farmer has or has not developed coping strategies to climate change (Table 4).

Independent variables include agro-ecological zone and altitude, age and education of the head of the household, household size, land holding, farmlabor, ability to pay/hire labor, ownership of livestock, non-farm income source, access to credit, social capital, farming experience, practice of irrigation, receiving weather forecast, intercropping on the farm, and the use of local signs to predict seasons.

Table 3. Description of model variables of the outcome equation for the Heckman probit selection model

\begin{tabular}{|c|c|c|}
\hline \multicolumn{3}{|l|}{ 1. Dependent variable } \\
\hline Description & $\begin{array}{l}\text { Farmers who } \\
\text { adapted (\%) }\end{array}$ & $\begin{array}{l}\text { Farmers who } \\
\text { did not adapt } \\
(\%)\end{array}$ \\
\hline $\begin{array}{l}\text { Adaptation to climate change (dummy: takes the value of } 1 \text { if farmer has adapted } \\
\text { and } 0 \text { otherwise) }\end{array}$ & 85.4 & 14.6 \\
\hline \multicolumn{3}{|l|}{ 2. Independent variables } \\
\hline Description & Mean & S.D. \\
\hline $\begin{array}{l}\text { Level of education of household head (dummy: takes the value of } 1 \text { if above A level } \\
\text { and } 0 \text { otherwise) }\end{array}$ & 0.06 & 0.2 \\
\hline Household size (continuous) & 7.5 & 4.3 \\
\hline Gender of household head (dummy: 1 if male otherwise 0 ) & 0.7 & 0.4 \\
\hline Off-farm income source (dummy: 1 if present otherwise 0 ) & 0.4 & 0.5 \\
\hline Livestock ownership (dummy: 1 if livestock owned otherwise 0 ) & 0.6 & 0.5 \\
\hline Extension information on sweetpotato crop (dummy: 1 if received otherwise 0 ) & 0.1 & 0.3 \\
\hline Total land holding (ha; continuous)) & 19.8 & 190.3 \\
\hline Credit (dummy: 1 if there is access otherwise 0 ) & 0.8 & 0.4 \\
\hline Intercropping (dummy: 1 if farmer intercrops and 0 if otherwise) & 0.9 & 0.3 \\
\hline Irrigation (dummy: 1 if farmer irrigates and 0 if otherwise) & 0.1 & 0.3 \\
\hline Number of farm workers (continuous) & 4.5 & 3.6 \\
\hline Ability to hire farm labor (dummy: 1 if hires labor and 0 otherwise) & 0.6 & 0.5 \\
\hline
\end{tabular}


Table 4. Results of the Heckman probit selection model (two-step)

\begin{tabular}{|c|c|c|c|c|}
\hline \multirow[t]{2}{*}{ Independent variables } & \multicolumn{2}{|c|}{$\begin{array}{l}\text { Regression values for adaptation } \\
\text { model }\end{array}$} & \multirow{2}{*}{$\begin{array}{l}\text { Regression } \\
\text { model }\end{array}$} & \multirow{2}{*}{$\begin{array}{c}\text { for perception } \\
\text { P value } \\
\end{array}$} \\
\hline & Coefficients & P value & & \\
\hline House hold size & 0.0073 & 0.8620 & & \\
\hline Livestock ownership & 0.4894 & 0.0670 & & \\
\hline Total land holding & -0.0261 & 0.0060 & & \\
\hline Access to Credit & 0.4977 & 0.0700 & & \\
\hline Intercropping & -0.0558 & 0.8470 & & \\
\hline Irrigation & 0.1259 & 0.7640 & & \\
\hline Ability to hire farm labor & 0.2482 & 0.3720 & & \\
\hline Number of farm workers & -0.0440 & 0.4450 & & \\
\hline Education & 0.0759 & 0.9020 & -0.0233 & 0.4950 \\
\hline Extension information on sweetpotato & -0.0065 & 0.9890 & -0.0044 & 0.8910 \\
\hline Off-farm income & 0.3850 & 0.1620 & 0.0294 & 0.0117 \\
\hline Gender of household head & 0.5734 & 0.0340 & 1.1592 & 0.0000 \\
\hline Age & & & 0.0027 & 0.0030 \\
\hline Social capital & & & 0.2055 & 0.1910 \\
\hline Climate information & & & -0.0044 & 0.8910 \\
\hline $\begin{array}{l}\text { Local knowledge of early warning } \\
\text { signs }\end{array}$ & & & 0.0115 & 0.4910 \\
\hline Farming experience & & & -0.0016 & 0.1010 \\
\hline Elevation & & & 0.0008 & 0.0000 \\
\hline AEZ is Northern farming system & & & 0.0006 & 0.9820 \\
\hline AEZ is South Western Highlands & & & -0.7574 & 0.0000 \\
\hline AEZ is Western Range Lands & & & 0.0844 & 0.0010 \\
\hline AEZ is Lake albert Crescent & & & -0.0241 & 0.3220 \\
\hline AEZ is Eastern Savannah & & & 0.1324 & 0.0000 \\
\hline AEZ is Lake Victoria Crescent & & & -0.0779 & 0.0180 \\
\hline lambda & 0.1036 & 0.0170 & & \\
\hline Number of observations & 179 & & & \\
\hline Censored observations & 28 & & & \\
\hline $\begin{array}{l}\text { Uncensored observations } \\
\text { Wald } \text { chi }^{2} 3643.88, \mathrm{p}=0.000\end{array}$ & 151 & & & \\
\hline
\end{tabular}

\section{Results}

\subsection{Farmers' Perceptions about Changes in Climatic Variables}

Nearly all the households (99\%) interviewed had observed a change in the climate in the last 10 years. The percentage of households reporting that rain came late $(47.6 \%)$ were nearly equal to those reporting rain to be coming early (47.1\%). Forty three percent reported that rain increased in amount and intensity while $36 \%$ perceive rain to be extreme (Figure 1). The highest proportion of farmers (39\% households) perceived an increase in temperature in the last 10 years, while $27 \%$ of the households did not observe any change in temperature (Figure 2). Extreme climatic events like floods, drought/prolonged dry seasons, and storms were reported to have increased in the last 10 years (Figure 3). Perception to climate change was indeed influenced by the agro-ecological zone; farmers in the northern farming system (Gulu), western range lands (Kasese), and eastern savannah (Soroti) perceiving more changes in climate variables than their counterparts in south western highlands (Kabale), Lake Victoria crescent (Wakiso), and Lake Albert crescent (Masindi). 


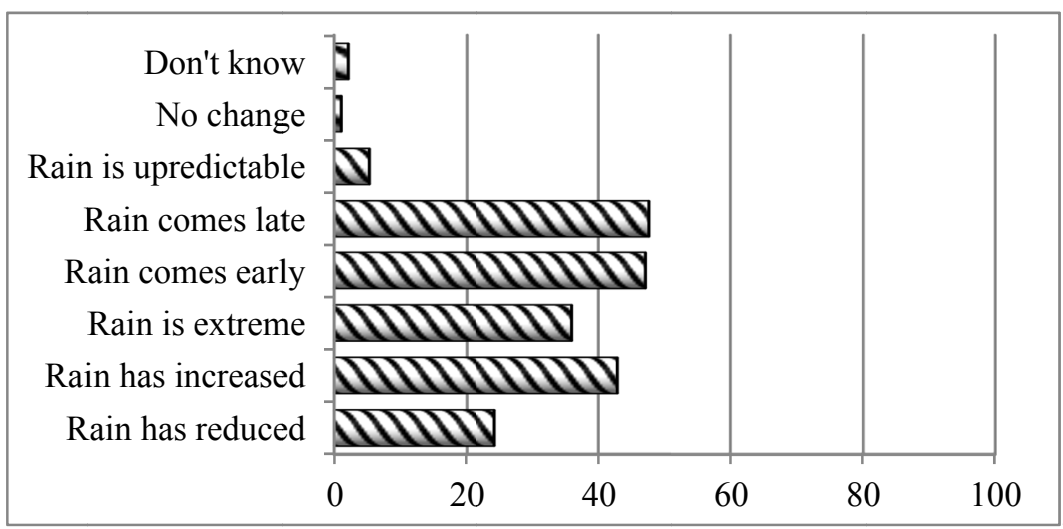

Figure 1. Farmer perception of changes in rainfall in the last 10 years (\% households)

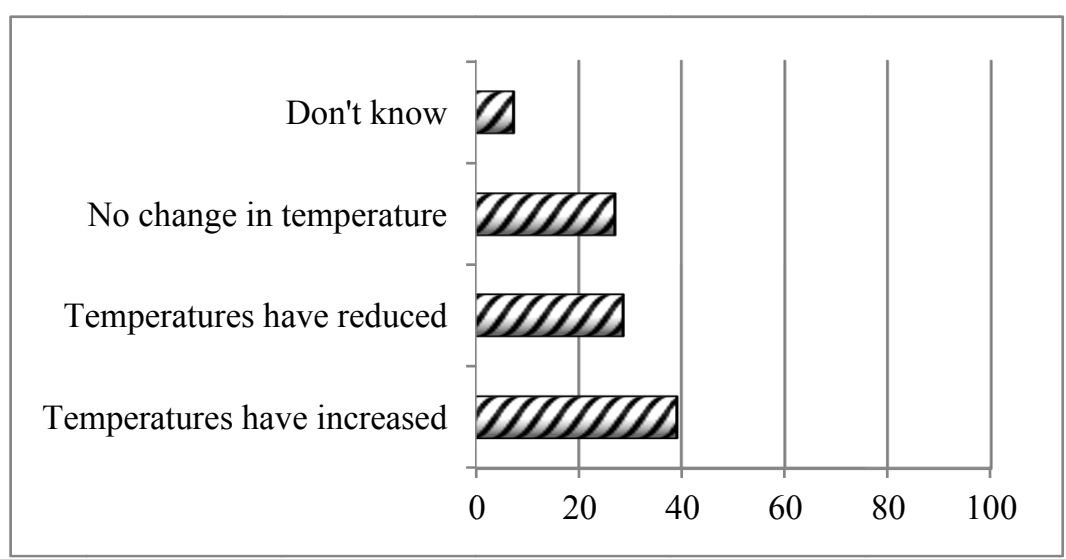

Figure 2. Farmer perception of changes in temperature (\% households)

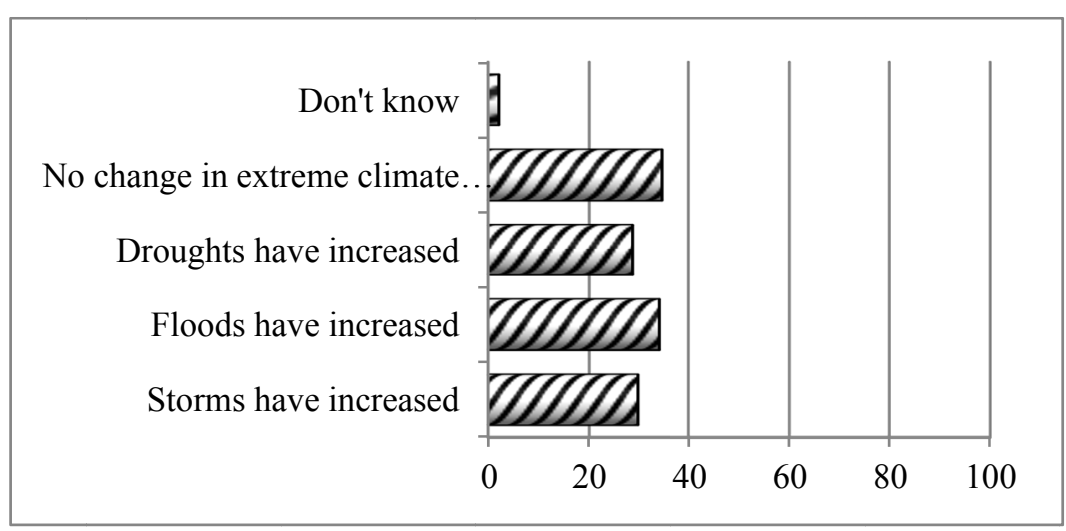

Figure 3. Change in the occurrence of extreme climatic events in the last 10 years (\% households)

\subsection{Factors Affecting Farmers' Strategies to Cope With Climate Change}

Only one variable, gender of the household head, positively and significantly influenced adaptation to climate change (Table 5); i.e., male headed households responded faster developing coping strategies. Other factors that positively affected the development of coping strategies were household size, livestock ownership, access to credit, irrigation practice, ability to hire farm labor at peak seasons, education of household head, and access to an off-farm income source. Larger size of land owned negatively and significantly affected adaptation. Other factors that had a negative relationship to adaptation to climate change included intercropping practice, higher number of farm workers, and access to extension information. 
Table 5. How changes in climate affected crop production

\begin{tabular}{|c|c|c|c|}
\hline $\begin{array}{l}\text { Climate change } \\
\text { event }\end{array}$ & Effect on crop production & Crop affected & $\%$ households \\
\hline Floods & $\begin{array}{l}\text { rotting of tubers and roots, } \\
\text { increased fungal diseases, loss } \\
\text { of gardens, reduced yields, soil } \\
\text { erosion, premature harvest of } \\
\text { grain crops, reduced farm land }\end{array}$ & $\begin{array}{l}\text { sweetpotato, potato, cassava, garden pea Pisum sativum L., } \\
\text { bean Phaseolus vulgaris L., greengram Vigna radiate (L.) R. } \\
\text { Wilczek, groundnut Arachis hypogaea L., tomato, eggplant } \\
\text { Solanum melongena L., cabbage Brassica oleracea L., maize, } \\
\text { rice, sorghum, sesame, watermelon Citrullus lanatus (Thunb.) } \\
\text { Matsum. \& Nakai, coffee, Taro Colocasia esculenta (L.) } \\
\text { Schott, orange Citrus spp. }\end{array}$ & 20 \\
\hline Mud slides/land slides & $\begin{array}{l}\text { takes away fertile soils, soil } \\
\text { erosion, washes away gardens }\end{array}$ & beans, potato, all crops & 1 \\
\hline $\begin{array}{l}\text { Drought/ prolonged } \\
\text { dry season }\end{array}$ & $\begin{array}{l}\text { complete crop failure, reduced } \\
\text { yields, drying up of crops, } \\
\text { increased pest damage }\end{array}$ & $\begin{array}{l}\text { sweetpotato, cassava, garden pea, common bean, green gram, } \\
\text { groundnut, soya bean Glycine max (L.) Merr., cowpea Vigna } \\
\text { unguiculata (L.) Walp., sorghum, sesame, maize, millet, red } \\
\text { pepper }\end{array}$ & 37 \\
\hline Longer and more rain & $\begin{array}{l}\text { longer growing time and } \\
\text { increased yields }\end{array}$ & sweetpotato, cassava, beans, groundnuts, maize & 5 \\
\hline $\begin{array}{l}\text { Changed onset and } \\
\text { cessation of rain } \\
\text { season) }\end{array}$ & $\begin{array}{l}\text { poor grain quality at harvest, } \\
\text { late planting, reduced yields, }\end{array}$ & potato, cassava, bean, groundnut, maize, sorghum, & 11 \\
\hline $\begin{array}{l}\text { Extreme/intensive/ } \\
\text { heavy rainfall }\end{array}$ & $\begin{array}{l}\text { rotting of bean pods and tubers, } \\
\text { reduced yields, cut-off roads, } \\
\text { soil erosion, reduced labor }\end{array}$ & sweetpotato, potato, bean, groundnut, sorghum & 19 \\
\hline $\begin{array}{l}\text { Storms (strong winds } \\
\text { and/or hailstones) }\end{array}$ & $\begin{array}{l}\text { destroyed leaves, broke shoots } \\
\text { and flowers, broke house, } \\
\text { reduce leaf quality }\end{array}$ & $\begin{array}{l}\text { sweetpotato, cassava, bean, tomato, maize, sorghum, sesame, } \\
\text { banana, pawpaw Carica papaya L., tobacco Nicotiana spp. }\end{array}$ & 11 \\
\hline
\end{tabular}

\subsection{Effect of Climate Change on Crop Production}

Changes in climate had already started to impact on farmers' crop production. On average, drought had the highest (37\% of the households) impact on crop production followed by floods ( $20 \%$ of the households) across agro-ecological zones (Table 6). For instance, floods caused rotting of potato (Solanum tuberosum L.) tubers and sweetpotato (Ipomoea batatas (L.) Lam.) and cassava (Manihot esculenta Crantz) roots, increased fungal diseases in potato, coffee (Coffea spp.) and tomato (Solanum lycopersicum L. ) crops, reduced crop yields, soil erosion, and premature harvest of grain crops and reduced farm land.

Table 6. Changes made in crop, soil and water management practices in the last 10 years

\begin{tabular}{lr}
\hline Change made (adaptation strategy) & Households (\%) \\
\hline Planted trees and/or hedges & 45.8 \\
Planted quick-maturing crop variety & 35.4 \\
Started or increased use of pesticides or fungicides & 33.3 \\
Planted new and/or high-yielding varieties of a crop & 26.0 \\
Planted drought-tolerant crop or variety & 23.4 \\
Applied mulch in a crop garden & 22.9 \\
Planted early or late in the season & 19.3 \\
Diversified income source to a non-farm income source & 18.2 \\
Planted disease-resistant crop variety & 18.2 \\
Practiced soil erosion protection methods & 17.7 \\
Stopped planting a crop or variety & 12.0 \\
Planted pest-resistant crop or variety & 11.5 \\
Practiced zero or no tillage & 9.4 \\
Increased irrigation & 1.0 \\
\hline
\end{tabular}

Total is more than 100 because of multiple responses, $n=192$. 


\subsection{Changes Made with Respect to Crop Varieties and in the Management of Crops, Soils and Water}

Farmers were asked for the changes which their households had made over the last 10 years following changes in the climate. Survey findings show that $45.8 \%$ of households had planted trees in the last 10 years (Table 7 ). Fruit trees were mostly planted for commercial sale of fruits and as a source of fuel (charcoal and/or firewood). Trees like pine, Pinus patula (Schiede ex Schltdl. \& Cham.), and Eucalyptus species were planted for their timber, building poles, fuel, and for soil erosion protection on the steep slopes of Kabale. Pinus species and Ficus species were planted mainly for improving soil fertility due to their association with soil fungus.

\subsection{Changes Made in Non-Farm Income Sources}

We examined the non-farm activities which farmers had taken on to diversify their income sources and therefore spread the risks associated with farming like total crop failure. A number of activities had been started to increase household cash income and included handcraft making, stone quarrying, retail business, working as a casual worker at another farm and securing salaried employment. No household had any new additional cash income activity in Gulu district (Figure 4). Retail business was the most common type of activity started by households $(16 \%)$ across the six districts.

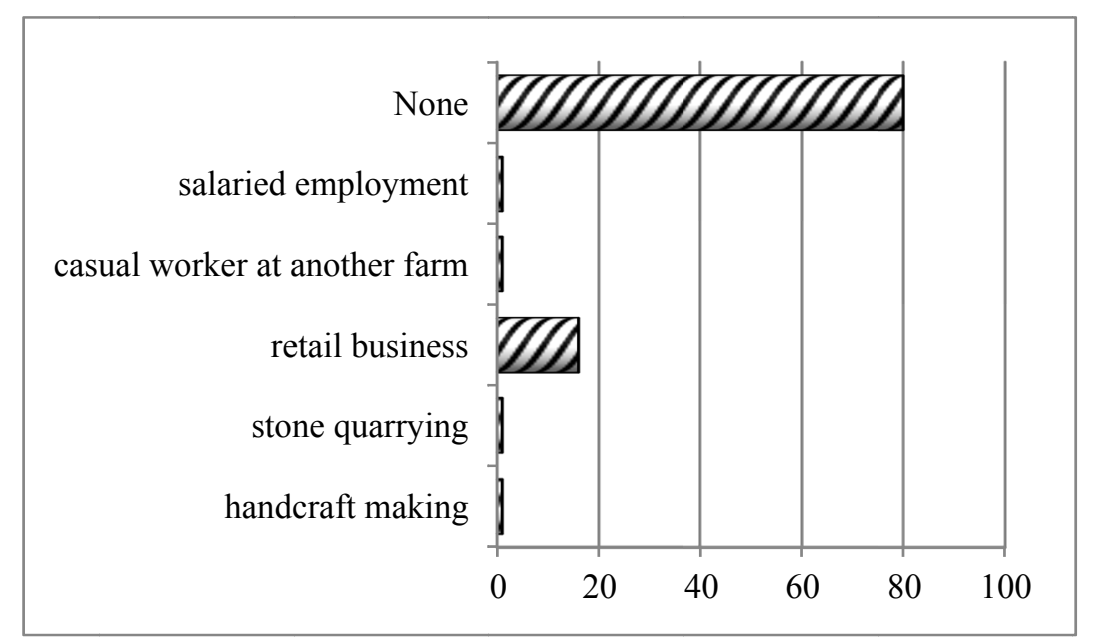

Figure 4. Changes made to diversifying from farm to non-farm activities

\section{Discussion}

Most of the farmers admitted to observing an increase in the amount and intensity of precipitation and an increase in temperature in the last 10 years. An increase in temperature in the last decades has been recorded in Uganda (MoWE, 2002; Nsubuga et al., 2011) and elsewhere in Africa, e.g., in Ethiopia (Mengistu, 2011), Ghana (Fosu-Mensah et al., 2010), and South Africa (Gbetibouo, 2009). Increased temperatures are said to be responsible for the increased floods reported for instance in Kasese district where the ice cap on Mt. Rwenzori has melted (Masereka \& Tenywa, 2000; Kaggwa et al., 2009). In Uganda, higher temperatures have already been reported to reduce crop yields in cereals and coffee reducing the area for coffee cultivation (MoWE, 2002; GoU, 2007; GoU, 2010; MoWE, 2010). Temperature increases have been reported to be responsible for extending the geographic range of some insects (pests and vectors) currently limited by temperature like mosquitoes (Anopheles spp.) in highland areas that were historically malaria-free, such as in Kabale, Kisoro and Rukungiri districts of Uganda now also experiencing epidemics (MoFPED, 2009) and the sorghum chafer (Pachnoda interrupta Olivier; Coleoptera: Scarabaeidae) which has now extended to the northeastern highlands of Ethiopia including the Afar regions (Demessie, 2004).

Rainfall across the country has been noted to be unreliable and highly variable in terms of its onset, cessation, amount, and distribution, leading to either low crop yields or total crop failure (MoWE, 2002; Mubiru et al., 2012). The increase in rainfall over the years in Uganda agrees with the prediction by the IPCC report of a likely increase in the annual mean rainfall in East Africa (Christensen et al., 2007). If deviations of such magnitude persist a little longer, they could affect the overall physiological activities of plants and result in crop failures and reduced yields. As a result, rainfed agriculture is quite sensitive to even small changes in temperature and rainfall (IPCC, 2007). 
Extreme weather events that had been experienced include drought and prolonged dry seasons, floods, storms/extreme rain and mud/landslides in order of decreasing occurrence. It is interesting to point out that extreme weather events have also had positive effects on agriculture like allowing for longer growing times due to plenty of rain hence resulting in increased crop yields especially in the Masindi district, while flooding created new opportunities for growing lowland rice (Oryza spp.).

Farmers manage risks, including those related to climate, regularly as part of their everyday lives. However, there is a need for farmers not only to cope with the impacts of a changing climate but rather to adapt in order to reduce the negative impact of climate change. Socioeconomic and environmental factors have a big role to play in the way farmers perceive and later adapt to impacts of a changing climate (Deressa et al., 2011). Coping strategies to protect farmers against climate related hazards included storing food, planting early and digging drainage channels. Other strategies included planting early-maturing varieties, high-yielding varieties, drought-tolerant varieties, disease- and/or pest-resistant varieties, income diversification, tree planting, increased pesticide/fungicide application, among others. Similar coping strategies were reported from various studies conducted in different parts of Africa like Ethiopia, South Africa and Nigeria (Giorgis et al., 2006; Hassan \& Nhemachena, 2008; Deressa et al., 2009; Salau, 2012). Adaptive capacity of smallholder farmers to changes in climatic events is usually low due to dependence on natural resources, constraints in human and physical capital, and poor infrastructure (Shewmake, 2008; Salau, 2012; Gukurume, 2013). In this survey, factors that hindered adaptation included poverty (inability to pay for farm inputs, equipment and services like labor), unreliable weather forecasts, and shortage of food to store, among others.

\section{Conclusions, Recommendations and Policy Implications}

Small-holder farmers need to be supported by government and civil society organizations in the adaptation process to use water resources more efficient in agriculture since rain has becoming more erratic and with delayed onsets of rainfall.

Government institutions need to put more efforts into providing farmers with accurate weather forecasts as most farmers have no confidence in the weather forecasts received. This will enable farmers to fully exploit seasonal rainfall distribution to improve and stabilize crop yields.

There is need for the government of Uganda to facilitate the development and dissemination of agricultural technologies such as integrated pest management (IPM) to substitute the use of pesticides as well as drought-tolerant and early-maturing varieties by research institutions through increased funding to the agricultural sector.

The development and application/use of modeling tools that support adaptation planning and decision making need to be supported and disseminated to scientists and policy makers as this will help in forecasting extreme climatic events like floods, mudslides, disease and pest outbreaks rather than responding to these serious events or outbreaks as is the case in Uganda.

\section{Acknowledgements}

The authors gratefully acknowledge the financial support for conducting this study that was provided by the Federal Ministry of Co-operation and Development (BMZ), Germany, for the project "Predicting climate-change-induced vulnerability of African agricultural systems to major insect pests through advanced insect phenology modeling, and decision aid development for adaptation planning". Further, we are thankful to the enumerators for translating the questions into local languages and to the district agriculture officers for supporting the survey.

\section{References}

Arbuckle, Jr., J. G., Morton, L. W., \& Hobbs, J. (2013). Farmer beliefs and concerns about climate change and attitudes toward adaptation and mitigation: Evidence from Iowa. Climatic Change. http://dx.doi.org/10.1007/s10584-013-0700-0

Byg, A., \& Salick, J. (2009). Local perspectives on a global phenomenon-Climate change in Eastern Tibetan villages. Global Environmental Change, 19, 156-166.

Christensen, J. H., Hewitson, B., Busuioc, A., Chen, A., Gao, X., Held, I., ... Whetton, P. (2007). Regional Climate Projections. In S. Solomon, D. Qin, M. Manning, Z. Chen, M. Marquis, K. B. Averyt, M. Tignor, \& H. L. Miller (eds.) Climate Change 2007: The Physical Science Basis. Contribution of Working Group I to the Fourth Assessment Report of the Intergovernmental Panel on Climate Change. Cambridge University Press, Cambridge, United Kingdom and New York, NY, USA. 
Cooper, P. J. M., Dimes, J., Rao K. P. C., Shapiro, B., Shiferaw, B., \& Twomlow, S. (2008). Coping better with current climatic variability in the rain-fed farming systems of sub-Saharan Africa: An essential first step in adapting to future climate change? Agriculture, Ecosystems and Environment, 126, 24-35. http://dx.doi.org/10.1016/j.agee.2008.01.007

Demessie, A. (2004). Effects of climate change on agriculture particularly in semi-arid tropics of the world with some examples of Ethiopian condition. Paper presented at BALWOIS 2004, Ohrid, FY Republic of $\begin{array}{lllll}\text { Macedonia, } & \text { 25-29 } & \text { May } & \text { Retrieved } & \text { from }\end{array}$ http://balwois.com/balwois/administration/full_paper/ffp-1p-229.pdf

Deressa, T. T., \& Hassan, R. M. (2009). Economic Impact of Climate Change on Crop Production in Ethiopia: Evidence from Cross-section Measures. Journal of African Economies, 18(4), 529-554. http://dx.doi.org/10.1093/jae/ejp002

Deressa, T. T., Hassan, R. M., \& Ringler, C. (2011). Perception of and adaptation to climate change by farmers in the Nile basin of Ethiopia. Journal of Agricultural Science, 149, 23-31. http://dx.doi.org/10.1017/S0021859610000687

Deressa, T. T., Hassan, R. M., Ringler, C., Alemu, T., \& Yusuf, M. (2009). Determinants of farmers' choice of adaptation methods to climate change in the Nile Basin of Ethiopia. Global Environmental Change, 248-255. http://dx.doi.org/10.1016/j.gloenvcha.2009.01.002

Dixon, J., Gulliver, A., \& Gibbon, D. (2001). Farming systems and poverty: improving farmers' livelihoods in a changing world. Rome and Washington, D.C., FAO and World Bank.

Fischer, G., Shah, M., \& van Velthuizen, H. (2002). Climate Change and Agricultural Vulnerability. International Institute for Applied Systems Analysis. Report prepared under UN Institutional Contract Agreement 1113 for World Summit on Sustainable Development. Laxenburg, Austria.

Fosu-Mensah, B. Y., Vlek, P. L. G., \& Manschadi, A. M. (2010). Farmers' Perception and Adaptation to Climate Change; A Case Study of Sekyedumase District in Ghana. Paper presented at Tropentag 2010 "World Food System-A Contribution from Europe”. 14-16th September, 2010, Zürich, Switzerland.

Gbetibouo, G. A. (2009). Understanding farmers' perceptions and adaptations to climate change and variability: The case of the Limpopo Basin, South Africa. Environment and Production Technology Division IFPRI Discussion Paper 00849, Washington DC, USA, 39pp.

Giorgis, K., Tadege, A., \& Tibebe, D. (2006). Estimating crop water use and simulating yield reduction for maize and sorghum in Adama and Miesso Districts using the CROPWAT model, CEEPA Discussion Paper No. 31, CEEPA, University of Pretoria.

GoU (Government of Uganda). (2007). Climate Change: Uganda National Adaptation Programmes of Action (NAPA). Department of Meteorology, Government of Uganda. Retrieved from http://www.climatechangeconcern.com/NAPA.Uganda.pdf

GoU (Government of Uganda). (2010). National development plan 2010/2011-2014/2015. Retrieved from http://www.finance.go.ug/docs/NDP_April_2010-Prot.pdf

Gukurume, S. (2013). Climate change, variability and sustainable agriculture in Zimbabwe's rural communities. Russian Journal of Agricultural and Socio-Economic Sciences, 2(14), 89-100.

Hassan, R., \& Nhemachena, C. (2008). Determinants of African farmers' strategies for adapting to climate change: Multinomial choice analysis. African Journal of Agricultural and Resource Economics, 2(1), 83-104.

Haque, A., Yamamoto, S. S., Malik, A. A., \& Sauerborn, R. (2012). Households' perception of climate change and human health risks: A community perspective. Environmental Health, 11(1), 1-12. http://dx.doi.org/10.1186/1476-069X-11-1.

IPCC (Intergovernmental Panel on Climate Change). (2007). Climate Change 2007: The Physical Science Basis. In K. B. Averyt, M. Tignor, \& H. L. Miller (Eds.). Cambridge: Cambridge University Press.

IPCC (Intergovernmental Panel on Climate Change). (2007b). Impacts, adaptations and vulnerability. Fourth Assessment Report, Cambridge University Press, Cambridge, UK.

Kaggwa, R., Hogan, R., \& Hall, B. (2009). Enhancing the Contribution of Weather, Climate and Climate Change to Growth, Employment and Prosperity. UNDP/NEMA/UNEP Poverty Environment Initiative, Kampala, Uganda. 
Kurukulasuriya, P., \& Mendelsohn, R. (2008). How Will Climate Change Shift Agro-Ecological Zones and Impact African Agriculture? Policy Research Working Paper 4717. Sustainable Rural and Urban Development Team, Development Research Group, The World Bank.

Lobell, D. B., Burke, M. B., Tebaldi, C., Mastrandrea, M. D., Falcon, W. P., \& Naylor, R. L. (2008). Prioritizing climate change adaptation needs for food security in 2030. Science, 319(5863), 607-610. http://dx.doi.org/10.1126/science.1152339

Maharjan, V., Sigdel, E. R., Sthapit, B. R., \& Regmi, B. R. (2011). Tharu community’s perception on climate changes and their adaptive initiations to withstand its impacts in Western Terai of Nepal. International NGO Journal, 6(2), 35-42.

Masereka B., \& Tenywa, G. (2000). Peak of Mount Rwenzori blocked. The New vision, Kampala Uganda. Retrieved from http://www.newvision.co.ug/D/8/13/718229

Mendelsohn, R., Dinar, A., \& Williams, L. (2006). The distributional impact of climate change on rich and poor countries. Environment and Development Economics, 11, 1-20.

Mengistu, D. K. (2011). Farmers' perception and knowledge on climate change and their coping strategies to the related hazards: Case study from Adiha, central Tigray, Ethiopia. Agricultural Sciences, 2(2), 138-145. http://dx.doi.org/10.4236/as.2011.22020

Mertz, O., Mbow, C., Reenberg, A., \& Diouf, A. (2009). Farmers' perceptions of climate change and agricultural adaptation strategies in rural Sahel. Environmental Management, 43(5), 804-16. http://dx.doi.org/10.1007/s00267-008-9197-0

MoFPED (Ministry of Finance, Planning and Economic Development). (2009). The State of Uganda Population Report 2009: Addressing the Effects of Climate Change on Migration Patterns and Women.

MoWE (Ministry of Water and Environment). (2002). Initial National Communication of Uganda to the Conference of the Parties to the United Nations Framework Convention on Climate Change. Ministry for Environment, Uganda. Retrieved from http://unfccc.int/resource/docs/natc/uganc1.pdf

MoWE (Ministry of Water and Environment). (2010). National statement at the 4th National Climate Change Forum, Uganda. 4 - 5 November 2010. Republic of Uganda. Retrieved from http://unfccc.int/files/meetings/cop_16/statements/application/pdf/101208_cop16_hls_uganda.pdf

Mubiru, D. N., Komutunga, E., Agona, A., Apok, A., \& Ngara, T. (2012). Characterising agro-meteorological climate risks and uncertainties: Crop production in Uganda. South African Journal of Science, 108(3/4), 470-480.

Nhemachena, C. (2009). Agriculture and future climate dynamics in Africa: Impacts and adaptation options. Ph.D. Thesis. Department of Agricultural Economics, Extension, and Rural Development, University of Pretoria, South Africa.

Nhemachena, C., \& Hassan, R. (2007). Micro-Level Analysis of Farmers' Adaptation to Climate Change in Southern Africa. IFPRI Discussion Paper No. 00714. International Food Policy Research Institute. Washington DC, USA.

Nsubuga, F. N. W., Olwoch, J. M., \& Rautenbach, C. J. (2011). Climatic Trends at Namulonge in Uganda: 1947-2009. Journal of Geography and Geology, 3(1), 119-131. http://dx.doi.org/10.5539/jgg.v3n1p119

Salau, E. S., Onuk E. G., \& Ibrahim, A. (2012). Knowledge, Perception and Adaptation Strategies to Climate Change among Farmers in Southern Agricultural Zone of Nasarawa State, Nigeria. Journal of Agricultural Extension, 16(2), 199-211.

Seo N. S., Mendelsohn, R., Dinar, A., Hassan, R., \& Kurukulasuriya, P. (2009). A Ricardian Analysis of the Distribution of Climate Change Impacts on Agriculture across Agro-Ecological Zones in Africa. Environment and Resource Economics, 43, 313-332. http://dx.doi.org/10.1007/s10640-009-9270-z

Shewmake, S. ( 2008). Vulnerability and the impact of Climate Change in South Africa's Limpopo River Basin, IFPRI Discussion Paper 00804. Washington, DC USA.

Stem, N. (2007). Stern Review on the Economics of Climate Change. Cambridge, UK: Cambridge University Press. 


\section{Copyrights}

Copyright for this article is retained by the author(s), with first publication rights granted to the journal.

This is an open-access article distributed under the terms and conditions of the Creative Commons Attribution license (http://creativecommons.org/licenses/by/3.0/). 